\title{
SEGMENTACJA NABYWCÓW NA PODSTAWIE ANALIZY CZYNNIKÓW WPEYWAJĄCYCH NA WYBÓR PRODUKTÓW ŻYWNOŚCIOWYCH
}

\begin{abstract}
Segmentacja rynku jest kluczowym etapem procesu projektowania strategii marketingowej każdego zorientowanego rynkowo przedsiębiorstwa, ponieważ stanowi podstawę wyboru docelowego nabywcy. Podstawowym celem segmentacji jest analiza struktury rynku ze szczególnym uwzględnieniem potrzeb klientów, którzy ten rynek tworzą. Dlatego też, precyzyjna wiedza o kliencie stanowi więc punkt wyjścia do przeprowadzenia segmentacji. W związku z tym kluczowe jest dokładne zidentyfikowanie i poznanie czynników wpływających na zachowania klientów. W wyniku właściwie przeprowadzonej segmentacji przedsiębiorstwo może przygotować konkurencyjną ofertę marketingową, dostosowaną do oczekiwań określonej grupy konsumentów przy efektywnym wykorzystaniu swoich zasobów.

Głównym celem publikacji jest przedstawienie możliwości wykorzystania metody grupowania k-średnich w procedurze segmentacji nabywców na rynku owoców i warzyw. W analizach statystycznych użyto wyniki badań sondażowych, z wykorzystaniem kwestionariusza ankiety, przeprowadzonych w 2016 roku na grupie 358 studentów. Do opracowania profilu nabywcy zastosowano analizę głównych składowych.

W wyniku zastosowania metody k-średnich autorzy wyodrębnili sześć względnie jednorodnych grup badanych nabywców na rynku owoców i warzyw. Zidentyfikowane grupy są na tyle zróżnicowane, że można zaproponować w oparciu o ich postawy i zachowania sprofilowane strategie marketingowe.
\end{abstract}

Słowa kluczowe: segmentacja rynku, metoda k-średnich, analiza głównych składowych, produkty żywnościowe.

\section{WPROWADZENIE}

W erze globalnej konkurencji, rewolucji informacyjnej i coraz szybciej zmieniających się uwarunkowań rynkowych ogromne znaczenie ma odpowiednie rozpoznanie i klasyfikacja nabywców. Działalność każdego podmiotu gospodarczego jest ściśle powiązana z klientem. We współczesnej gospodarce to właśnie klient jest największą strategiczną wartością funkcjonujących przedsiębiorstw. Klient poprzez nabywanie produktów lub usług każdorazowo decyduje o tym czy konkretne podmioty gospodarcze mają rację bytu na rynku. Dzięki „orientacji na klienta” przedsiębiorstwo jest w stanie zrealizować swoje cele rynkowe, zarówno te w wymiarze operacyjnym, jak i strategicznym. Przedsiębiorstwo, które nie ma klientów, nie przetrwa na rynku, ponieważ generując stratę nie może się rozwijać

\footnotetext{
${ }^{1}$ Dr Marek Angowski, Katedra Zarządzania i Marketingu, Wydział Agrobioinżynierii, Uniwersytet Przyrodniczy w Lublinie.

${ }^{2}$ Dr hab. Tomasz Kijek, Wydział Ekonomiczny, Uniwersytet Marii Curie-Skłodowskiej w Lublinie.
} 
i ostatecznie zniknie z rynku. W związku z tym konieczne jest dostarczenie klientowi tego, czego pragnie, w odpowiedniej ilości i jakości, po atrakcyjnej dla niego cenie, we właściwych miejscach i czasie ${ }^{3}$.

Głównym celem publikacji jest przedstawienie możliwości aplikacji analizy głównych składowych do opracowania profilu nabywcy produktów na rynku owoców i warzyw. Stworzone profile opisujące czynniki wpływające na zakup produktu zostały następnie wykorzystane w procedurze segmentacji. Część analityczna została opracowana na podstawie wyników badań sondażowych, przy użyciu kwestionariusza ankiety.

\section{ISTOTA I ZNACZENIE SEGMENTACJI}

Wzrastająca konkurencja sprawia, że aby przedsiębiorstwo mogło zdobyć i utrzymać odpowiednią pozycję oraz osiągnąć swoje cele rynkowe menedżerowie muszą znaleźć skuteczny sposób dotarcia do klientów ${ }^{4}$.

Idealną sytuacją dla przedsiębiorstwa byłaby znajomość wszystkich potencjalnych klientów i możliwość zaspokojenia ich indywidualnych wymagań i potrzeb. Jest to jednak niemożliwe z punktu widzenia organizacji rynku, dostępnej wiedzy, technologii a przede wszystkim ze względu na koszty. Poza tym nie można zapewnić najwyższego możliwego poziomu obsługi każdemu klientowi, przy jednoczesnym uwzględnianiu jego zróżnicowanych indywidualnie potrzeb, jak i jego różnej roli w generowaniu wielkości przychodów (klient kluczowy i marginalny, stały i jednorazowy) - jest to po prostu zbyt kosztowne i w konsekwencji nieopłacalne ${ }^{5}$.

Dlatego warto wyróżnić najbardziej wartościowych, najistotniejszych dla przedsiębiorstwa klientów i traktować ich odpowiednio z punktu widzenia realizacji celów rynkowych. W związku z tym rodzi się potrzeba segmentacji klientów, czyli podziału potencjalnych nabywców na grupy, które mają podobne potrzeby oraz prawdopodobnie w zbliżony sposób zareagują na różne działania marketingowe. Segmentacja rynku pozwala także na profilowanie klientów polegające na łączeniu klientów w tzw. grupy docelowe. Do tak wyodrębnionych grup klientów łatwiej można dopasowywać ofertę rynkową ${ }^{6}$.

Segmentacja jest metodą analizowania złożonej natury potrzeb, percepcji i oczekiwań klientów przez zakwalifikowanie ich do ograniczonej liczby homogenicznych grup, czyli

${ }^{3}$ H. Hall, Nowy konsument a zmiany $w$ metodach jego badania, Prace Naukowe Uniwersytetu Ekonomicznego we Wrocławiu, 336 (2014), s. 164; S.D. Hunt, D.B. Arnett, Marketing Segmentation Strategy, Competitive Advantage, and Public Policy: Grounding Segmentation Strategy in Resource-Advantage Theory, Australasian Marketing Journal, 12/1 (2004), s. 7-8; M.C.D. Verain, J. Bartels, H. Dagevos, S. J. Sijtsema, M.C. Onwzen, G. Antonidies, Segments of sustainable food consumers: a literature review, International Journal of Consumer Studies, 36 (2012), s. 124; Y. Xia, Competitive strategies and market segmentation for suppliers with substitutable products, European journal of Operational Research, 210 (2011), s. 195.

${ }^{4}$ G. Martin, The Importance of Marketing Segmentation, "American Journal of Business Education", 4/6 (2011), s. 15.

5 A. Reed, M.R. Forehand, S. Puntoni, L. Warlop, Identity-based consumer behavior, "International Journal of Research in Marketing" 29 (2012), s. 310; D. Roszkowska-Hołosz, Determinants of consumer purchasing behavior, "Management" 17/1 (2013), s. 333-335.

6 A. Gracia, Consumer's preferences for a local food product: a real choice experiment, "Empirical Economics", 47/1 (2014), s. 112; S. Sun, An Analysis on the Conditions and Methods of Market Segmentation, "International Journal of Business and Management", 4/2 (2009) s. 63. 
grup ludzi o podobnych potrzebach, percepcji lub oczekiwaniach, pragnieniach i wymaganiach”. W wyniku segmentacji formułuje się bardziej optymalną ofertę marketingową, dostosowaną do oczekiwań określonej grupy konsumentów, a nie całego rynku?

Segmentacja nabywców może z jednej strony służyć lepszemu zaspokajaniu potrzeb klientów, a z drugiej - koncentracji działań firmy na klientach generujących największe korzyści. Konsekwencją segmentacji portfela klientów jest różnicowanie wymiany między klientami z różnych segmentów. Po dokonaniu segmentacji firma musi wybrać segment, w którym chce sprzedawać swoje towary.

Głównym celem segmentacji jest analiza struktury rynku, czyli potrzeb klientów, które rynek tworzą. Wiedza o kliencie stanowi więc podstawę do rozpoczęcia jakiejkolwiek segmentacji. W związku z tym kluczowe staje się zidentyfikowanie i poznanie czynników wpływających na zachowania klientów. Zebrane informacje umożliwiają przewidywanie zachowań klientów oraz przygotowanie odpowiednich ofert marketingowych, sprzedażowych, aby korespondowały z potrzebami i oczekiwaniami klientów ${ }^{8}$.

Drugim celem segmentacji jest pozycjonowanie produktu, czyli nadanie mu, w odbiorze klientów, pewnych specyficznych atutów, wyróżniających produkt względem konkurentów i innych segmentów.

Przedsiębiorstwa w różny sposób przeprowadzają segmentację klientów. Jest ona jednym z podstawowych sposobów skutecznego zarządzania przedsiębiorstwem, co wprost wiąże się ze strategią rozwoju firmy, uzyskaniem przewagi konkurencyjnej oraz odpowiednim wykorzystaniem jej zasobów ${ }^{9}$.

Skuteczność segmentacji rynku zależy od przyjęcia odpowiednich kryteriów, które pozwolą wyjaśnić różnice w zachowaniach między grupami nabywców. W literaturze dotyczącej segmentacji rynku spotykamy bardzo dużą liczbę różnych kryteriów opisujących rynek i konsumentów uwzględniające szersze i węższe ujęcia, bardziej ogólne i szczegółowe, odnoszące się różnych kategorii nabywców dóbr i usług ${ }^{10}$.

Najczęściej spotykana klasyfikacja kryteriów segmentacji rynku dzieli je na kryteria odnoszące się do konsumenta oraz kryteria odnoszące się do produktu (lub sytuacji zakupu) - tabela 1 .

${ }^{7}$ B. Pilarczyk, M. Sławińska, H. Mruk, Strategie marketingowe przedsiębiorstw handlowych, Warszawa 2001, s. 134; S. Żakowska-Biemans, K. Gutkowska, M. Sajdakowska, Segmentacja konsumentów z uwzględnieniem skłonności do zaakceptowania innowacji w produktach żywnościowych pochodzenia zwierzęcego, „Handel Wewnętrzny” 4/345 (2013), s. 142.

8 D. Bubiel, Marketing aspect of young consumer behavior in food industry management, Zeszyty Naukowe Szkoły Głównej Gospodarstwa Wiejskiego, Ekonomika i Organizacja Gospodarki Żywnościowej, 112 (2015), s. 18-19; E. Czernyszewicz, Jakość owoców $i$ warzyw w ocenie konsumenckiej, ,Żywność. Nauka i technologia. Jakość”, 5/78 (2011), s. 174; V.A. N.F. Karakaya, Consumer segments in organic foods market, ,Journal of Consumer Marketing”, 31/4 (2014), s. 274; M. Angowski, K. Domańska, A. Komor, Wptyw działań promocyjnych na zachowania zakupowe młodych konsumentów na rynku żywności, Annales Universitatis Mariae Curie-Skłodowska, Sectio H-Oeconomia, 51/2 (2017), s. 10.

9 G. Walsh, T. Henning-Thurau, V. Wayne-Mitchel, K.P. Wiedmann, Consumers' decision-making style as a basic for market segmentation, "Journal of Targeting. Measurement and Analysis for Marketing", 10/2 (2001), s. 120-121.

${ }^{10}$ K. Mazurek-Łopacińska (red.), Badania marketingowe. Teoria i praktyka, Warszawa 2005, s. 296-297. 
Tabela 1. Kryteria segmentacji rynku

\begin{tabular}{|c|c|c|c|c|c|}
\hline \multicolumn{6}{|c|}{ Kryteria segmentacji rynku } \\
\hline $\begin{array}{c}\text { społeczno- } \\
\text { ekonomiczne }\end{array}$ & demograficzne & psychologiczne & $\begin{array}{c}\text { kryteria odnoszące się do produktu/sytuacji } \\
\text { zakupu } \\
\text { konsumpcji }\end{array}$ & $\begin{array}{c}\text { warunki } \\
\text { zakupu }\end{array}$ & $\begin{array}{c}\text { oferowane } \\
\text { korzyści }\end{array}$ \\
\hline $\begin{array}{c}\text { dochód, } \\
\text { zawód, } \\
\text { wykształcenie, } \\
\text { miejsce } \\
\text { zamieszkania }\end{array}$ & $\begin{array}{c}\text { wiek, płeć, } \\
\text { wielkość } \\
\text { i struktura } \\
\text { rodziny, faza } \\
\text { w cyklu życia } \\
\text { rodziny, status } \\
\text { rodziny }\end{array}$ & $\begin{array}{c}\text { styl życia, } \\
\text { aktywność, } \\
\text { zainteresowania } \\
\text { opinie }\end{array}$ & $\begin{array}{c}\text { sposób } \\
\text { użytkowania, } \\
\text { posiadanie } \\
\text { innych pro- } \\
\text { duktów, } \\
\text { lojalność } \\
\text { wobec marki } \\
\text { produktu }\end{array}$ & $\begin{array}{c}\text { rodzaj } \\
\text { sklepu, czas } \\
\text { zakupu, } \\
\text { okazje, } \\
\text { wielkość } \\
\text { zakupu, czę- } \\
\text { stotliwość } \\
\text { zakupu, }\end{array}$ & $\begin{array}{c}\text { wiedza o pro- } \\
\text { dukcie, umie- } \\
\text { jętność } \\
\text { postrzegania } \\
\text { korzyści, } \\
\text { predyspozycje } \\
\text { nabywców do } \\
\text { kupowania } \\
\text { i konsumo- } \\
\text { wania }\end{array}$ \\
\hline
\end{tabular}

Źródło: K. Mazurek-Łopacińska (red.), Badania marketingowe. Teoria i praktyka, Warszawa 2005, s. 295-296; B. Janczewska, Segmentacja uczestników rynku przemystowego, Annales Universitatis Mariae Curie-Skłodowska Lublin, Sectio H, XXXVII (2003), s. 347, A. Kusińska, Analizy wielowymiarowe jako źródto wiedzy o zachowaniach konsumentów na rynku, Prace Naukowe Uniwersytetu Ekonomicznego we Wrocławiu, 336 (2014), s. 92.

Niezależnie od typu oraz charakteru zastosowanych kryteriów należy pamiętać o dwóch podstawowych zasadach dokonywania segmentacji. Po pierwsze, nie ma kryteriów uniwersalnych, nadających się do zastosowania w odniesieniu do każdego produktu i każdej sytuacji rynkowej. Po drugie, dokonywanie segmentacji rynku jest procesem ciągłym, wymagającym stałego badania cech konsumentów i różnic pomiędzy nimi oraz dostosowywania programu działania do zachodzących zmian ${ }^{11}$.

Określenie segmentów rynku ma również istotne znaczenie dla ustalenie profilu i skali działalności przedsiębiorstwa. W zależności od posiadanych zasobów i ekonomicznego potencjału firma może podejmować decyzje o obsłudze jednego lub większej liczby segmentów. Dla przedsiębiorstwa atrakcyjny segment to taki, dla którego istnieje realna szansa przekształcenia potencjalnych konsumentów w nabywców. W związku z tym, aby to umożliwić potencjalne segmenty powinny nie tylko spełniać kryteria identyfikacji czy jednorodności, ale również odznaczać się następującymi cechami ${ }^{12}$ :

- wrażliwość, czyli reakcja rynku na te same działania marketingowe powinna być podobna wewnątrz segmentu, ale różna w każdym oddzielnym segmencie.

- mierzalność - segment powinien dać się zmierzyć i opisać w formie liczb w sposób umożliwiający przeprowadzenie skutecznej strategii marketingowej.

${ }^{11}$ L. Garbarski, I. Rutkowski, W. Wrzosek, Marketing, Warszawa 1994, s. 122.

12 M. Baker, S. Hart, Marketing Book, Elsevier Ltd., Oxford 2008, s. 223-225; L. Schiffman, A. O'Cass, A. Paladino, J. Carlson, Consumer behavior, 6th Edition, Pearson Education Australia, Frenchs Forest, NSW, s. 36-37; M. Wedel, W. Kamakura, Market segmentation. Conceptual and Methodological Foundations, 2nd Edition, International Series in Quantitative Marketing, Springer Science \& Business Media, 2012, DOI: https://doi.org/10.1007/978-1-4615-4651-1, s. 4-5. 
- dostępność, polegająca na możliwości efektywnego działania, np. dostęp do kanałów dystrybucji, do mediów czy różnego rodzaju pozwolenia prawne, koncesje, licencje itp.

- odpowiednia rozległość, czyli segment powinien być rentowny w przypadku stosowania indywidualnej strategii, a w przypadku braku rentowności powinna istnieć możliwość łączenia mniejszych grup w większe segmenty.

- segment powinien być stabilny $\mathrm{w}$ czasie, $\mathrm{z}$ punktu widzenia np.: wielkości, zasobności, rodzaju i typów zachowań konsumenckich.

\section{DANE I METODY}

Część empiryczna została opracowana na podstawie wyników badań sondażowych, które były przeprowadzone w 2016 roku na grupie 358 studentów przy wykorzystaniu metody doboru celowego. Główną metodą zbierania danych była metoda CAWI wspomagana metodą PAPI. Kwestionariusz został przygotowany $\mathrm{w}$ wersji elektronicznej i powiązany $\mathrm{z}$ bazą danych (Surveymonkey). Kwestionariusz składał się z 18 pytań problemowych dotyczących oceny zachowań i postaw nabywców na rynku produktów żywnościowych ze szczególnym uwzględnieniem czynników kształtujących proces wyboru oraz pytania charakteryzujące respondenta. Badania dotyczyły czterech grup produktowych: mięsa i jego przetworów, owoców i warzyw, produktów mleczarskich i piekarniczych.

W celu przeprowadzenia segmentacji rynku nabywców warzyw i owoców oraz ich przetworów autorzy wykorzystali procedurę badawczą obejmującą następujące etapy/czynności:

- Zredukowanie liczby zmiennych charakteryzujących preferencje zakupowe nabywców za pomocą analizy głównych składowych.

- Wyznaczenie liczby segmentów przy wykorzystaniu metody Warda z regułą stop opartą na indeksie Calińskiego-Harabasza.

- Przeprowadzenie segmentacji rynku w oparciu o metodę k-średnich.

Metoda głównych składowych wykorzystana w 1 . etapie procesu badawczego polega na transformacji obserwowalnych zmiennych pierwotnych w nowe wzajemnie ortogonalne zmienne, tzw. główne składowe ${ }^{13}$. W zapisie macierzowym model analizy głównych składowych przyjmuje postać układu równań:

$$
\begin{aligned}
& Z^{T}=B S^{T} \\
& S=B^{T} Z
\end{aligned}
$$

gdzie: $Z$ - macierz standaryzowanych zmiennych pierwotnych,

$B$ - macierz współczynników głównych składowych,

$S$ - macierz głównych składowych,

$T$ - znak transpozycji.

${ }^{13}$ E. Gatnar, M. Walesiak, Metody statystycznej analizy wielowymiarowej w badaniach marketingowych, Wrocław 2004, s. 194. 
Wyznaczone wartości na głównych składowych stanowiły podstawę do przeprowadzenia segmentacji rynku. Użyto w tym celu dwóch najczęściej stosowanych metod analizy skupień, tj. hierarchicznej metody Warda oraz niehierarchicznej metody k-średnich z przyjętą liczbą skupień wynikającą z metody Warda. Zasadność wyboru wskazanych metod potwierdzają liczne studia literaturowe poświęcone ocenie skuteczności procesów grupowania wielowymiarowych obiektów ${ }^{14}$

Metoda Warda bazuje na analizie wariancji i zakłada łączenie tych obiektów, które powodują możliwie najmniejszy przyrost wariancji w skupieniu. Zgodnie z założeniami metody na każdym etapie grupowania $k(k=1, \ldots n-1)$ dla $n-k$ istniejących skupień należy wyznaczyć sumę kwadratów odchyleń od średniej w obrębie każdego skupienia (Balicki 2009). W sytuacji analizy jednowymiarowej (cecha $X_{j}$ ) wariancja w skupieniu wynosi:

$$
W_{g}^{(k)}=\sum_{i=1}^{n_{g}}\left(x_{i j}-\bar{x}_{j}\right)^{2}(g=1, \ldots, n-k)
$$

Dla każdego możliwego podziału na danym etapie łączenia obliczany jest wskaźnik:

$$
W^{(k)}=\sum_{g=1}^{n-k} W_{g}^{(k)}
$$

gdzie: $n_{g}$ - liczba elementów w skupieniu $g$,

$x_{i j}$ - wartość cechy $i$-tej jednostki $\left(\mathrm{i}=1, \ldots, n_{g}\right)$ w skupieniu $g$.

W ostatnim etapie badania wykorzystano metodę k-średnich, której istota polega na optymalizowaniu pewnej funkcji jakości podziału obiektów. Jak zauważa Gatnar, funkcję jakości można zapisać w postaci formuły maksymalizującej ślad macierzy wariancji międzygrupowej lub minimalizującej ślad macierzy wariancji wewnątrzgrupowej ${ }^{15}$. Zgodnie $\mathrm{z}$ istotą metody k-średnich algorytm postępowania zmierzający do uzyskania jak najbardziej podobnych obiektów wewnątrz danego skupienia sprowadza się do tego, że wstępnie tworzy się k-losowych skupień, a w kolejnych krokach przenosi się obiekty między skupieniami, tak aby minimalizować zmienność wewnątrz skupień i maksymalizować zmienność między skupieniami.

\section{WYNIKI}

W tabeli 2 zaprezentowano wyniki analizy głównych składowych. W oparciu o kryterium stopnia wyjaśniania wariancji, które ustalono na poziomie $65 \%$, wyodrębniono 6 głównych składowych. Interpretując zakres informacji przenoszonych przez poszczególne składowe, zidentyfikowano profile zakupowe nabywców występujące w próbie badanych respondentów. Utworzony zbiór profili konsumentów można scharakteryzować następująco:

${ }^{14}$ K. Najman, Symulacyjna analiza wpływu wyboru kryterium optymalności podziału obiektów na jakość uzyskanej klasyfikacji a algorytmach k-średnich, Taksonomia 15, Prace Naukowe Uniwersytetu Ekonomicznego we Wrocławiu, 7(2008), s. 295-304.

15 E. Gatnar, Symboliczne metody klasyfikacji danych, Warszawa 1998, s. 29. 
Tabela 2. Macierz rotowanych składowych

\begin{tabular}{|c|c|c|c|c|c|c|}
\hline \multirow{2}{*}{ Czynniki wpływające na decyzje zakupowe } & \multicolumn{6}{|c|}{ Składowa } \\
\hline & 1 & 2 & 3 & 4 & 5 & 6 \\
\hline Wygląd produktu & $-0,049$ & 0,012 & 0,087 & $\mathbf{0 , 7 7 5}$ & 0,155 & 0,113 \\
\hline Smak & 0,025 & 0,107 & 0,113 & $\mathbf{0 , 8 3 3}$ & 0,013 & $-0,178$ \\
\hline Zapach & 0,000 & $-0,035$ & 0,196 & 0,809 & 0,004 & 0,034 \\
\hline Gatunek & 0,010 & 0,112 & 0,487 & 0,419 & 0,029 & 0,141 \\
\hline Skład produktu & 0,057 & 0,148 & 0,786 & 0,174 & 0,018 & $-0,067$ \\
\hline Walory odżywcze & 0,003 & 0,075 & $\mathbf{0 , 8 5 8}$ & 0,182 & 0,076 & 0,096 \\
\hline Brak konserwantów & 0,029 & 0,173 & 0,761 & 0,232 & 0,153 & 0,193 \\
\hline Świeżość produktu & $-0,131$ & 0,050 & 0,195 & 0,600 & 0,097 & 0,303 \\
\hline Data przydatności do spożycia & $-0,013$ & 0,162 & 0,240 & 0,501 & 0,162 & 0,274 \\
\hline Certyfikaty jakości & 0,171 & 0,615 & 0,360 & 0,087 & $-0,110$ & 0,202 \\
\hline Tradycyjne receptury & 0,248 & 0,647 & 0,379 & 0,031 & $-0,017$ & 0,127 \\
\hline Zdrowotność produktu & $-0,046$ & 0,471 & 0,342 & 0,282 & 0,052 & 0,214 \\
\hline Wygląd opakowania & 0,121 & 0,741 & 0,036 & 0,100 & 0,244 & 0,140 \\
\hline Wielkość opakowania & 0,194 & 0,691 & 0,024 & 0,067 & 0,318 & 0,074 \\
\hline Marka produktów & 0,244 & 0,667 & 0,146 & 0,101 & 0,238 & 0,138 \\
\hline Wyrób ekologiczny/bio & 0,254 & 0,591 & 0,350 & $-0,121$ & 0,079 & 0,170 \\
\hline Cena produktu & 0,092 & 0,146 & 0,093 & 0,139 & 0,793 & 0,145 \\
\hline Rabaty cenowe & 0,317 & 0,151 & 0,115 & 0,053 & 0,780 & $-0,022$ \\
\hline Dostępność w punkcie sprzedaży & 0,134 & 0,216 & 0,090 & 0,102 & 0,715 & 0,161 \\
\hline Degustacje w miejscu sprzedaży & 0,533 & 0,558 & 0,057 & $-0,044$ & 0,115 & $-0,157$ \\
\hline Programy lojalnościowe & $\mathbf{0 , 5 7 3}$ & 0,551 & 0,060 & $-0,020$ & 0,161 & $-0,140$ \\
\hline Ekspozycja w miejscu sprzedaży & 0,572 & 0,408 & $-0,043$ & 0,059 & 0,194 & $-0,063$ \\
\hline Promocje handlowe w miejscu sprzedaży & 0,504 & 0,251 & $-0,088$ & 0,151 & 0,444 & $-0,101$ \\
\hline Reklama telewizyjna & $\mathbf{0 , 8 4 7}$ & 0,123 & 0,089 & $-0,079$ & 0,126 & 0,124 \\
\hline Reklama radiowa & $\mathbf{0 , 8 7 3}$ & 0,156 & 0,133 & $-0,126$ & 0,041 & 0,071 \\
\hline Reklama w prasie & 0,871 & 0,127 & 0,094 & $-0,115$ & 0,070 & 0,121 \\
\hline Reklama na billboardach & $\mathbf{0 , 8 7 0}$ & 0,081 & 0,063 & $-0,025$ & 0,155 & 0,133 \\
\hline Rekomendacje rodziny/znajomych & 0,541 & $-0,047$ & $-0,002$ & 0,074 & 0,148 & 0,473 \\
\hline Rekomendacje sprzedawcy & 0,634 & 0,159 & $-0,015$ & 0,020 & 0,102 & 0,323 \\
\hline $\begin{array}{l}\text { Pozytywne opinie o produkcie/producencie } \\
\text { w mass mediach }\end{array}$ & 0,700 & 0,146 & $-0,003$ & 0,042 & 0,014 & 0,289 \\
\hline Przyzwyczajenie & 0,311 & 0,024 & $-0,143$ & 0,235 & 0,085 & $\mathbf{0 , 6 1 8}$ \\
\hline Kraj pochodzenia produktu & 0,198 & 0,237 & 0,183 & 0,099 & 0,041 & $\mathbf{0 , 7 3 7}$ \\
\hline Producent $\mathrm{z}$ regionu & 0,221 & 0,284 & 0,251 & 0,049 & 0,119 & 0,665 \\
\hline Moda & 0,627 & 0,384 & 0,150 & 0,040 & 0,069 & 0,097 \\
\hline
\end{tabular}

Źródło: opracowanie własne.

1) „Łowca nowości” - konsument uwzględniający w decyzjach zakupowych informacje pochodzące z przekazów reklamowych, dla którego szczególne znaczenie mają moda, różne formy reklamy i rekomendacje (składowa 1).

2) „Świadomy i roztropny” - konsument zorientowany na aspekty zdrowotne żywności potwierdzone certyfikatami, poszukujący produktów ekologicznych o tradycyjnych 
recepturach, dla którego istotna jest marka i opakowanie oraz możliwość degustacji wyrobów przed zakupem (składowa 2).

3) „Ekspert” - konsument ceniący jakość, na którą składają się walory odżywcze, skład produktu, gatunek, brak konserwantów (składowa 3).

4) „Smakosz” - konsument kierujący się wyglądem, smakiem, zapachem, świeżością i przydatnością do spożycia produktów (składowa 4).

5) „Racjonalista” - konsument zwracający uwagę na cenę, rabaty i dostępność produktów w miejscu sprzedaży (składowa 5).

6) „Tradycjonalista” - konsument o stałych preferencjach, kupujący produkty regionalne (składowa 6).

Zgodnie z przyjętą metodyką badania liczba skupień została ustalona w oparciu o metodę Warda, przy wykorzystaniu odległości euklidesowych. Uzyskane wyniki prezentuje dendogram (rys. 1). Poziom odcięcia dendogramu decydujący o liczbie skupień określono w oparciu o wskaźnik Calińskiego-Harabasza.

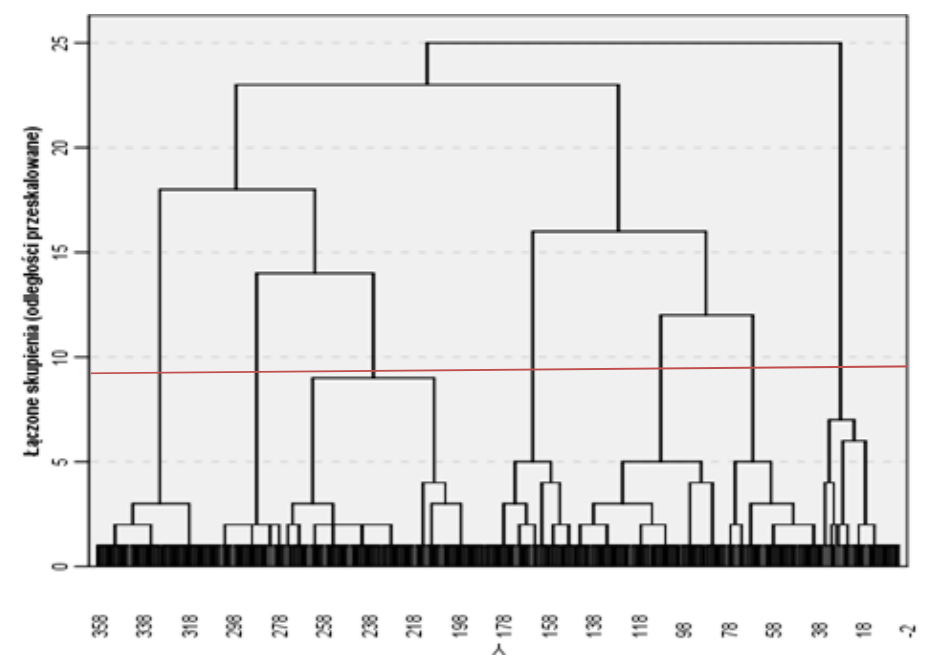

Rys. 1. Diagram drzewkowy

Źródło: opracowanie własne.

W następnym kroku wyodrębniono 8 skupień (segmentów) przy zastosowania metody k-średnich. Dla wyodrębnionych skupień obliczono przeciętne wartości na poszczególnych składowych (tabela 3). Uzyskane wyniki wskazują, że w segmencie 1 dominują konsumenci, którzy z jednej strony uwzględniają w decyzjach zakupowych informacje pochodzące z przekazów reklamowych i rekomendacje innych osób, zaś z drugiej strony zdecydowanie mniejszą wagę przywiązują do smaku i wyglądu produktów. W przypadku segmentu 2 zachowania zakupowe nabywców z tej grupy najlepiej opisywane są przez składową 2 i 6, która charakteryzuje konsumentów o stałych preferencjach i poszukujących produktów regionalnych o określonych walorach zdrowotnych. Jeżeli chodzi o segmenty 3 i 4, to można powiedzieć, że konsumenci z tych skupień w swoich decyzjach nabywczych 
kierują się głównie takimi cechami produktów, jak: wygląd, smak, zapach, świeżość i przydatność do spożycia. Dla nabywców zaliczonych do segmentu 5 duże znaczenie mają produkty regionalne $\mathrm{z}$ określonego kraju pochodzenia oraz przyzwyczajenie. Z kolei, konsument zorientowany na produkty ekologiczne o tradycyjnych recepturach, dla którego istotne są moda, marka i opakowanie oraz możliwość degustacji wyrobów przed zakupem jest reprezentatywnym typem nabywcy dla segmentu 6 . W przypadku segmentu 7 o wyborach nabywców decydują aspekty zdrowotne poparte przekazem reklamowym. Ostatecznie konsumentów tworzących skupienie 8 najlepiej opisuje profil zakupowy nabywcy, dla którego wyznacznikami atrakcyjności oferty są cena, rabaty i dostępność produktów w miejscu sprzedaży.

Tabela 3. Ostateczne centra skupień

\begin{tabular}{|l|c|c|c|c|c|c|c|c|}
\hline & \multicolumn{7}{|c|}{ Skupienie } \\
\cline { 2 - 9 } & 1 & 2 & 3 & 4 & 5 & 6 & 7 & 8 \\
\hline Składowa 1 & $\mathbf{0 , 3 3 7 9 0}$ & $-0,65310$ & 0,02256 & $-0,27599$ & $-0,83559$ & $-0,92362$ & $\mathbf{0 , 9 6 8 7 2}$ & 0,15018 \\
\hline Składowa 2 & 0,09217 & $\mathbf{0 , 7 6 2 8 4}$ & $-0,12262$ & $-0,33402$ & $-0,46909$ & $\mathbf{1 , 2 3 4 0 3}$ & $\mathbf{0 , 5 8 9 2 1}$ & $-1,12873$ \\
\hline Składowa 3 & $-0,53693$ & $-1,49198$ & $-1,65503$ & 0,16268 & 0,43685 & $\mathbf{0 , 4 7 7 8 6}$ & 0,36343 & 0,30171 \\
\hline Składowa 4 & $-2,48822$ & $-2,18416$ & $\mathbf{0 , 6 3 6 9 4}$ & $\mathbf{0 , 4 5 6 1 7}$ & 0,03802 & $-0,03459$ & 0,20541 & 0,09878 \\
\hline Składowa 5 & $-0,36342$ & $-0,87761$ & 0,25983 & $-1,71553$ & 0,29525 & 0,41930 & 0,13946 & $\mathbf{0 , 4 8 9 9 3}$ \\
\hline Składowa 6 & $-0,27989$ & $\mathbf{1 , 5 9 0 1 3}$ & $-0,00862$ & $-0,23235$ & $\mathbf{1 , 0 4 2 4 1}$ & $-0,74546$ & 0,16855 & $-0,81228$ \\
\hline
\end{tabular}

Źródło: opracowanie własne.

Biorąc pod uwagę liczebności wyodrębnionych skupień, największy segment, tj. skupienie 7, tworzą nabywcy, których preferencje zakupowe najlepiej opisuje składowa 1 i 2 (tabela 4). Co ciekawe, dla tego segmentu wartości na pozostałych składowych są wyższe od wartości przeciętnych. Taka sytuacja może sugerować istnienie znacznej grupy nabywców, którzy w procesie zakupowym kierują się szerokim spektrum wyróżników oferty rynkowej. Drugim pod względem liczebności jest segment 5. W przypadku tej grupy nabywców można mówić o bardziej jednoznacznym profilu zakupowym. Opisuje on konsumentów o stałych preferencjach, kupujących produkty regionalne, którzy są mało podatni na oddziaływanie przekazów reklamowych. Należy zauważyć, że segmentem, który można uznać za niszowy jest skupienie 2. Pomimo że tę grupę nabywców można sprofilować podobnie jak skupienie $5 \mathrm{w}$ oparciu o analizę wartości na 6 składowej, to warto podkreślić jej całkowity brak podobieństwa do charakterystyk zakupowych prezentowanych przez pozostałe składowe poza składową 2 .

Tabela 4. Liczba obserwacji w każdym skupieniu

\begin{tabular}{|c|c|c|c|c|c|c|c|c|c|}
\hline Skupienie & 1 & 2 & 3 & 4 & 5 & 6 & 7 & 8 & Suma \\
\hline Liczebność & 24 & 6 & 47 & 41 & 61 & 39 & 88 & 52 & 358 \\
\hline
\end{tabular}

Źródło: opracowanie własne. 


\section{ZAKOŃCZENIE}

Podsumowując przedstawione w artykule rozważania i analizy, można sformułować następujące wnioski:

- Segmentacja rynku jest kluczowym etapem procesu projektowania strategii marketingowej każdego zorientowanego rynkowo przedsiębiorstwa, ponieważ stanowi podstawę wyboru docelowego nabywcy. Właściwy dobór nabywcy to nie tylko terytorialny obszar działania, ale przede wszystkim skuteczniejszy sposób dotarcia do klienta przy pomocy konkretnych instrumentów marketingowych, a w efekcie niższe koszty, mniejsze ryzyko, wyższa rentowność czy lepsza pozycja konkurencyjna.

- W obecnych uwarunkowania rynkowych, gdzie przedsiębiorstwo działa w warunkach dynamicznie zmieniającego się rynku, dużej i intensywnej konkurencji, zachowań i postaw nabywców charakteryzujących się dużą zmiennością (niekiedy również nieprzewidywalnością) należy poszukiwać coraz bardziej kompleksowych metod segmentacji rynku.

- Podstawowym wyzwaniem analityków rynku jest grupowanie danych w konkretne struktury. Analiza skupień jest jednym z narzędzi umożliwiających tworzenie grup obiektów, w taki sposób, aby stopień powiązania obiektów z obiektami należącymi do tej samej grupy był jak największy a z obiektami z pozostałych grup jak najmniejszy. Kryteriami grupującymi te obiekty mogą być między innymi zachowania i postawy konsumentów.

- W publikacji wykorzystano metodę analizy głównych składowych, metodę Warda i metodę k-średnich. W wyniku zastosowania wymienionych metod statystycznych wyodrębniono sześć względnie jednorodnych grup badanych nabywców na rynku owoców i warzyw. Zidentyfikowane grupy są na tyle zróżnicowane, że można zaproponować w oparciu o ich postawy i zachowania sprofilowane strategie marketingowe. Zróżnicowanie miedzy grupami pozwala na przygotowanie i zastosowanie odmiennych narzędzi marketingowych przede wszystkim w obszarach koncepcji produktu, strategii cenowej i komunikacji marketingowej.

\section{LITERATURA}

[1] Angowski M., Domańska K., Komor A., Wpływ działań promocyjnych na zachowania zakupowe młodych konsumentów na rynku żywności, Annales Universitatis Mariae Curie-Skłodowska, Sectio H-Oeconomia, 51/2 (2017), s. 10.

[2] Baker M., Hart S., Marketing Book, Elsevier Ltd., Oxford, 2008.

[3] Bubiel D., Marketing aspect of young consumer behavior in food industry management, Zeszyty Naukowe Szkoły Głównej Gospodarstwa Wiejskiego, Ekonomika i Organizacja Gospodarki Żywnościowej, 112 (2015).

[4] Czernyszewicz E., Jakość owoców $i$ warzyw w ocenie konsumenckiej, „Żywność. Nauka i technologia. Jakość", 5/78 (2011).

[5] Gatnar E., Symboliczne metody klasyfikacji danych, PWN, Warszawa 1998.

[6] Gatnar E, Walesiak M., Metody statystycznej analizy wielowymiarowej $w$ badaniach marketingowych, AE, Wrocław 2004.

[7] Garbarski L., Rutkowski I., Wrzosek W., Marketing, PWE, Warszawa 1994. 
[8] Gracia A., Consumer's preferences for a local food product: a real choice experiment, "Empirical Economics", 47/1 (2014), s. 112,

[9] Hall H, Nowy konsument a zmiany w metodach jego badania, Prace Naukowe Uniwersytetu ekonomicznego we Wrocławiu, 336 (2014), s. 164.

[10] Hunt S.D., Arnett D.B., Marketing Segmentation Strategy, Competitive Advantage, and Public Policy: Grounding Segmentation Strategy in Resource-Advantage Theory, “Australasian Marketing Journal”, 12/1 (2004), s. 7-8.

[11] Janczewska B., Segmentacja uczestników rynku przemystowego, Annales Universitatis Mariae Curie-Skłodowska Lublin, Sectio H, XXXVII (2003), s. 347.

[12] Kusińska A., Analizy wielowymiarowe jako źródto wiedzy o zachowaniach konsumentów na rynku, Prace Naukowe Uniwersytetu Ekonomicznego we Wrocławiu, 336 (2014), s. 92.

[13] Martin G., The Importance of Marketing Segmentation, "American Journal of Business Education", 4/6 (2011), s. 15.

[14] Mazurek-Łopacińska K. (red.), Badania marketingowe. Teoria i praktyka, PWN, Warszawa 2005.

[15] Najman K., Symulacyjna analiza wptywu wyboru kryterium optymalności podziału obiektów na jakość uzyskanej klasyfikacji a algorytmach k-średnich, Taksonomia 15. Prace Naukowe Uniwersytetu Ekonomicznego we Wrocławiu, 7(2008), s. 295-304.

[16] Nasir V.A., Karakaya F., Consumer segments in organic foods market, "Journal of Consumer Marketing", $31 / 4$ (2014), s. 274.

[17] Pilarczyk B., Sławińska M., Mruk H., Strategie marketingowe przedsiębiorstw handlowych, PWE, Warszawa 2001.

[18] Reed A., Forehand M. R., Puntoni S., Warlop L., Identity-based consumer behavior, "International Journal of Research in Marketing", 29 (2012), s. 310.

[19] Roszkowska-Hołosz D., Determinants of consumer purchasing behavior, "Management", 17/1 (2013), s. 333-335.

[20] Schiffman L., O’Cass A., Paladino A., Carlson J., Consumer behavior, 6th Edition, Pearson Education Australia, Frenchs Forest, NSW, s. 36-37.

[21] Sun S., An Analysis on the Conditions and Methods of Market Segmentation, "International Journal of Business and Management", 4/2 (2009) s. 63.

[22] Verain M.C.D., Bartels J., Dagevos H., Sijtsema S.J., Onwzen M.C., Antonidies G., Segments of sustainable food consumers: a literature review, "International Journal of Consumer Studies", 36 (2012), s. 124.

[23] Walsh G., Henning-Thurau T., Wayne-Mitchel V., Wiedmann K. P., Consumers' decisionmaking style as a basic for market segmentation, "Journal of Targeting. Measurement and Analysis for Marketing", 10/2 (2001), s. 120-121.

[24] Wedel M., Kamakura W., Market segmentation. Conceptual and Methodological Foundations, 2nd Edition, International Series in Quantitative Marketing, Springer Science \& Business Media, 2012, DOI: https://doi.org/10.1007/9.

[25] Xia Y., Competitive strategies and market segmentation for suppliers with substitutable products, "European journal of Operational Research", 210 (2011), s. 195.

[26] Żakowska-Biemans S., Gutkowska K., Sajdakowska M., Segmentacja konsumentów $z$ uwzględnieniem sktonności do zaakceptowania innowacji w produktach żywnościowych pochodzenia zwierzęcego, „Handel Wewnętrzny” 4/345 (2013), s. 142. 


\section{BUYERS SEGMENTATION BASED ON THE ANALYSIS OF FACTORS AFFECTING SELECTION OF THE PRODUCT IN THE FOOD MARKET}

Market segmentation is the key stage of a marketing strategy development process. It results from the fact that the market segmentation is a starting point of the target consumer choice for every market-driven enterprise. The main aim of the segmentation is to analyze consumers' needs which create a market. The initiation of any segmentation process builds on knowledge about a client. It is, therefore, crucial for the precise identification and examination of factors affecting consumers' behaviors. As a result of the right segmentation, the enterprise, using effectively its resources, can create the competitive marketing proposition adapted to expectations of a particular group of consumers.

The main purpose of the paper is to present the possibilities of using the k-means method to conduct the customers segmentation in the fruits and vegetables market. The results of a questionnaire survey on the group of 356 students conducted in 2016 were used in statistical analyses. In order to find a consumer profile the principal component analysis was employed. The k-means method allowed the authors to find six homogenous groups of consumers in the fruits and vegetables market. The identified groups are so heterogeneous that it is possible to profile marketing strategies on the basis of customers attitudes and behaviors.

Keywords: market segmentation, k-means method, principal component analysis, food products.

DOI: $10.7862 /$ rz.2017.hss.40

Przestano do redakcji: lipiec 2017 r.

Przyjęto do druku: wrzesień 2017 r. 